\title{
Research article: Problems faced by agricultural extension functionaries in using information and communication technology tools
}

Dishant Jojit James and M.T. Lakshminarayan

Article Chronicle: Received : 14.05.2018;

Revised : 13.06.2018; Accepted :

27.06.2018

KEY WoRds: ICT tools, Transfer of technology, Agricultural extension functionaries

Dishant Jojit James Department of Agricultural Extension, G.K.V.K., University of Agricultural Sciences, Bengaluru (Karnataka) India

Email : dishantjj@gmail.

com

See end of the article for authors' affiliations
SUMMARY : The present study was carried out in Mysuru, Hassan, Mandya and Tumakuru districts of Karnataka state during 2016-2017 to know the profile of agricultural extension functionaries and to identify the problems faced by the agricultural extension functionaries in using ICT tools. A sample of 80 Agricultural Officers ( 30 Nos) and Assistant Agricultural Officers (50 Nos) representing 43 Raitha Samparka Kendras of four sampled districts were interviewed with the help of a pre-tested interview schedule. The results revealed that majority of the extension functionaries were educated upto M.Sc. (Agri) degree $(51.25 \%)$, had undergone training on ICT tools $(60.00 \%)$ and were having medium level of e-readiness $(51.25 \%)$. Majority of the agricultural extension functionaries had the problem of interrupted power supply, slow/ poor internet connection, poor maintenance of ICT tools, inadequate number of ICT tools (multimedia projectors, tablets with GPS, DVDs, digital cameras, etc.), lack of upgraded ICT tools/ equipment (hardware/software), high cost of ICT tools, technical and infrastructural problems, less number of Agri websites and portals, and problems of virus and junk mails. All the agricultural extension functionaries suggested for uninterrupted power supply for effective utilization of ICT tools, while a majority of agricultural extension functionaries suggested for allocation of sufficient funds for ICT infrastructure and procurement/ upgrading/ maintenance of ICT equipment and tools, provision of better internet connectivity etc., for effective utilization of ICT tools.

How to cite this article : James, Dishant Jojit and Lakshminarayan, M.T. (2018). Problems faced by agricultural extension functionaries in using information and communication technology tools. Agric. Update, 13(3): 283-288; DOI : 10.15740/HAS/AU/13.3/283-288. Copyright@2018: Hind Agri-Horticultural Society. 